\title{
Vegetation cover and carbon pool loss assessment due to extreme weather induced disaster in Mandakini valley, Western Himalaya
}

\author{
Kumar Yogesh ${ }^{1,2}$, Babu Sanjay ${ }^{2}$ and Singh Sarnam ${ }^{2,3}$ 的
}

Received: 28.12 .2019

Revised: 07.02.2020

Accepted: 19.04.2020

\begin{abstract}
Sendai Framework for 2015-2030 emphasises on the damage and loss assessment needs and its ecosystem level impacts. We have assessed the loss of forest cover and phytomass/carbon pool in the natural forest ecosystems lost due to extreme weather conditions leading flash floods and landslides during Kedarnath tragedy on June 17, 2013 in Mandakini Valley, Uttarakhand in Western Himalaya. We used high resolution satellite IRS LISS IV (5.8 m spatial resolution) of predisaster (2012) \& post-disaster (2013). Since lost vegetation cannot be ground inventoried, a new approach was developed wherein we used pre-disaster spectral characteristics to identify sample locations in nearby and adjacent to affected areas. We laid 45 geotagged sample plots in May 2014 on both side of the 37 landslide affected areas within a distance of 2 km from river-bed for primary data collection. Above ground biomass and Carbon was estimated using standard protocols and used species-specific volumetric equations and wood density. Above ground biomass varied from 18.05t/ha in Alpine Scrub to 252.95 t/ha in Subtropical forests. Assuming that the biomass increment and spectral properties would not change significantly, we applied several vegetation indices to get best regression model with biomass. We found NDVI (2014) with coefficient of determination $\left(\mathrm{R}^{2}\right)$ of $0.893, \mathrm{SE} \pm \mathbf{0 . 0 3 8}$ with linear function as the best for geospatial modelling of the biomass for pre-flood 2013 and post-flood 2014 situations. Coefficient of determination ( $R^{2}$ ) between estimated visà-vis modelled biomass was $\mathbf{0 . 8 6 4 3}$. It is found that there is a net loss of 52,055.80 tonnes of forest biomass and $24,466.14$ tonnes of carbon due to landslides and flash floods. The maximum biomass/carbon was lost in the sub-tropical forests. The loss of forest cover was maximum in subtropical forests.
\end{abstract}

Key Words: Extreme Rainfall, Flash Floods, Landslides, Forest Cover Damage, Carbon Pool Loss, Remote Sensing, Vegetation Indices, Spectral Modelling

\section{Introduction}

Natural disasters such as extreme weather events or cloud bursts induced floods and landslides, windstorms, cyclones, Typhoons, Tsunami, volcanos, earthquakes, forest fires, etc. cause extensive damage and loss to property, infrastructure, settlement, lives (human and livestock), forest cover, biodiversity, soil loss, soil organic carbon, crop-land, etc. These disasters leave behind hundreds of people dead or injured and residue of damaged property (Naithani et al.., 2001; Wyss, 2005; Sengupta et al., 2010; Kala, 2014; Mishra, 2015) and are reported well by media to draw the attention of government and society.

\section{Author's Address}

${ }^{1}$ Ministry of Environment Forest and Climate Change, New Delhi, India

${ }^{2}$ Indian Institute of Remote Sensing, Dehradun 248001, Uttarakhand, India

${ }^{3}$ School of Ecology and Environment Studies, Nalanda University, Rajgir, Bihar, 803116, India

E-mail.: sarnam.singh@gmail.com
However, damage and loss caused to vegetation/forest cover, timber, biodiversity including wildlife and its ecosystem services are given the least attention

Incessant rainfall combined with or with-out windstorm cause wide-spread damage to forest cover particularly in mountainous terrain. The vegetation being static, cannot be saved from such events. Even though Sendai Framework (2015-30) calls for ecosystem-based disaster risk reduction and management but invariability government agencies, society, donors, rehabilitation agencies, etc. discuss only about 'select' aspects of disaster, the reporting on forest fire is limited to burnt area, pollution, release of $\mathrm{CO}_{2}$ and other greenhouse gases.

In recent times some of the most devastating natural mega-disasters in Asia Pacific region were the Asian Tsunami (26 December 2004), Cyclone Nargis in Myanmar (2 May, 2008), Haiti earthquake (12 January, 2010), Monsoon floods in 
Pakistan (2010), Japan Tsunami (11 March 2011), Kedarnath disaster (16-17 June, 2013), Phailin (October 2013), Hudhud (October 2014), J\&K flood (2014), Nepal earthquake (2015), Tsunami in Indonesia (2018), etc. causing wide-spread damage. Realizing the importance of human sufferings and potential of Earth Observation data United Nations established United Nations Space Based Information and Disaster and Emergency Response (UN-SPIDER) in 2006 to offer policy advice and facilitating capacity building services including strategic learning, research, training, system development and exchange of information for effective disaster risk reduction and management and liaison with governments, industries, local organizations, communities, etc. by encouraging use of space-based information but forgetting 'sufferings' of vegetation/forest and biodiversity. Off late UNESCO has focused on management of Natural World Heritage sites to protect and conserve wildlife from disasters. The United Nations Economic Commission for Latin America and Caribbean (UN-ECLAC) developed a methodology for Damage and Loss Assessment (DaLA) to quantify the economic losses (CGI, 2005; Cutter et al., 2006; Scawthorn et al., 2006; Hallegatte and Przyluski, 2010; Lang et al., 2012). The damage and losses due to episodic events such as flash floods and landslides in Himalaya have been reported by Gupta and Joshi (1990), Anbalagan (1992); Pachauri and Pant (1992); Sarkar et al. (1995); Mehrotra et al. (1996); Nagarajan et al. (1998); Kanungo et al. (2006); Pareta and Pareta (2012); Gupta et al. (2013).

The lofty and young Himalayan mountains, the most unique formations and global chain of megabiodiversity hotspots are highly vulnerable to earthquake, cloud burst, extreme rainfall event, flash floods, landslide due to heavy rainfall, forest fires, etc. (Kessarkar et al., 2011; Manish et al., 2013; Jha et al., 2016; Gupta et al., 2018). The Himalaya is categorized as severe to very high landslide hazard prone by Building Materials and Technology Promotion Council (BMTPC). The north-western Himalayan region is a meeting point of the south-western meteorological monsoonal phenomenon originating from Bay of Bengal as well as western disturbances originating from Mediterranean and Arabian sea, that cause frequent cloudbursts and widespread torrential rains, flash floods and landslides. A massive disaster, Himalayan Tsunami, struck on June 16-17, 2013 in Uttarakhand after torrential rainfall of $385.1 \mathrm{~mm}$ against normal rainfall of $71.3 \mathrm{~mm}$. Maximum damage occurred in Bageshwar, Chamoli, Pithoragarh, Rudraprayag and Uttarkashi and of these Mandakini valley in Rudraprayag district was worst affected. The incessant rain and cloudburst in upper Kedarnath valley caused melting of Chorabari glacier, overflow and collapse of moraine dammed Chorabari lake (Fig.1). These events caused sudden and severe floods and landslides in Mandakini river catchment (Fig. 2) and sedimentation of rivers leading to loss riparian vegetation (Fig.3). More than 5500 human lives, settlements, infrastructure, machinery, livestock, agriculture land, forest areas etc. were lost (Kumar, 2013; Bajpai et al., 2014; Das, 2013; Rao et al., 2014). Vast majority of these reports were concerning on widespread damage and impact on human, livestock, infrastructure and property (Fig. 4). There was hardly any report/literature which detailed about damage and loss of forest cover, biodiversity, biomass, carbon, etc. which is caused by disasters (fig. 5, 6). Soni et al. (2008) reported loss of 2050 trees of Chir Pine (Pinus roxburghii) due to Varunavat landslide in Uttarkashi and loss of 396.4 tonnes of carbon from vegetation and 0.25 tonnes from shrubs. An inventory on landslides triggered due to Kedarnath tragedy was carried out by the National Remote Sensing Centre (NRSC) for the affected area using pre and post satellite data (http://bhuvannoeda.nrsc.gov.in /disaster/disaster.php). Therefore, the present study highlights loss of natural vegetation/forest cover and biomass/carbon in Mandakni river catchment due to disaster.

Satellite data are widely used for mapping and monitoring global forest cover for the past 50 years and characterization of biophysical parameters using medium to coarse resolution data (Dadhwal et al., 1997; Chhabra et al., 2002; Ramachandran et al., 2007; Kale et al., 2009; Bijalwan et al., 2010; Pandey et al., 2010; Thakur and Swamy, 2010; Kumar et al., 2011; Patil et al., 2012). We have attempted to develop a new sampling approach to assess the lost biomass using high resolution satellite data, where ground inventory of lost biomass was not possible. 


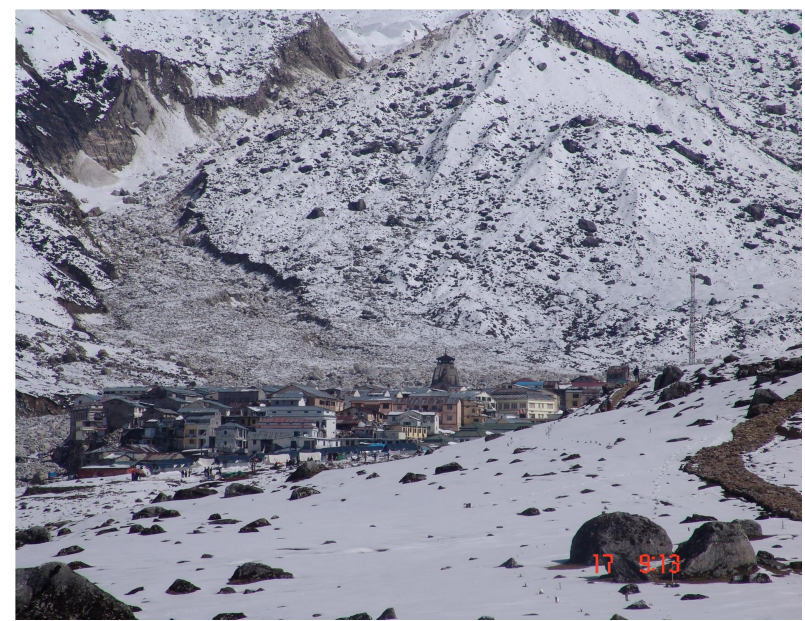

Fig. 1 Terminus channel of the Chorabari glacier in north-west of Kedarnath shrine

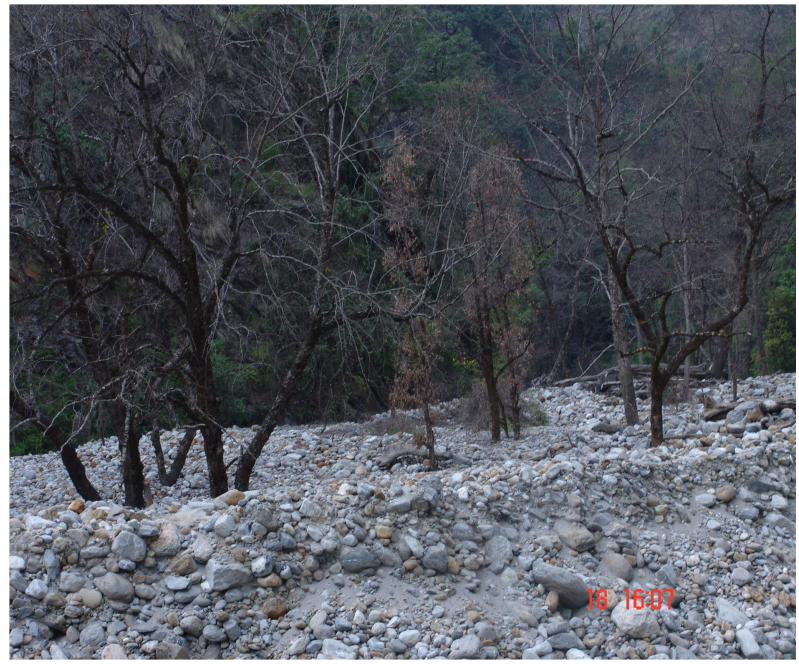

Fig. 3. Dead riparian vegetation due to debris deposition near Sonprayag in Son Ganga river

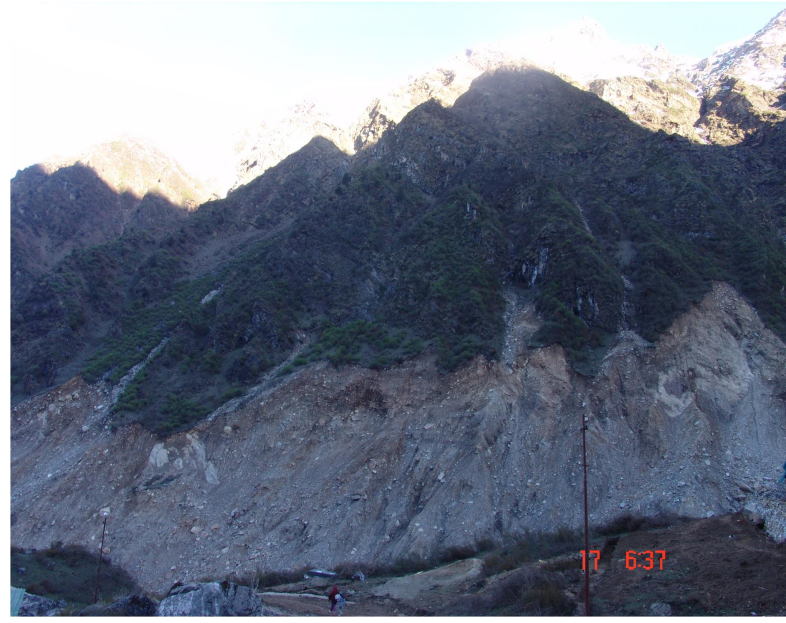

Fig. 5. Huge landslide causing damage and loss of temperate and subalpine forest opposite Lincholi camp

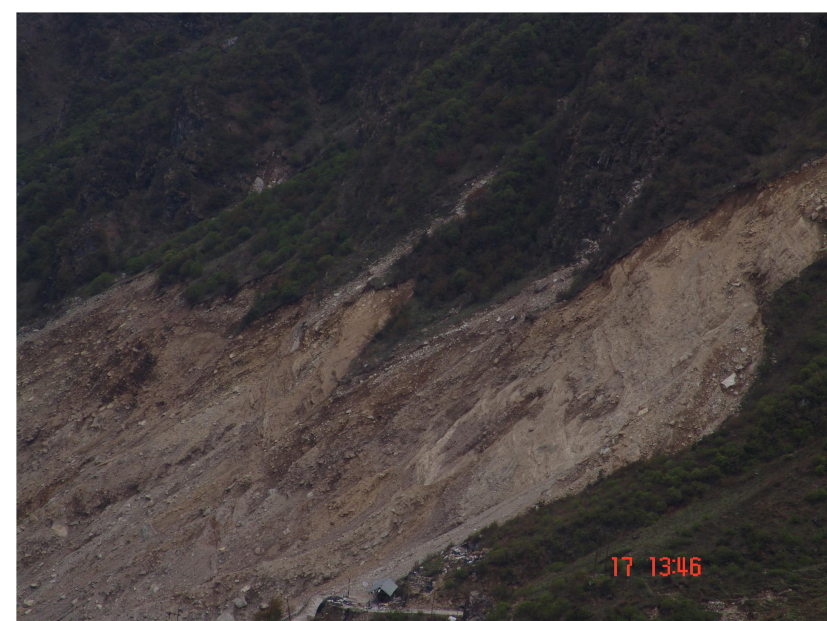

Fig. 2. Huge landslide in sub-temperate zone, destroyed Temperate Scrub vegetation

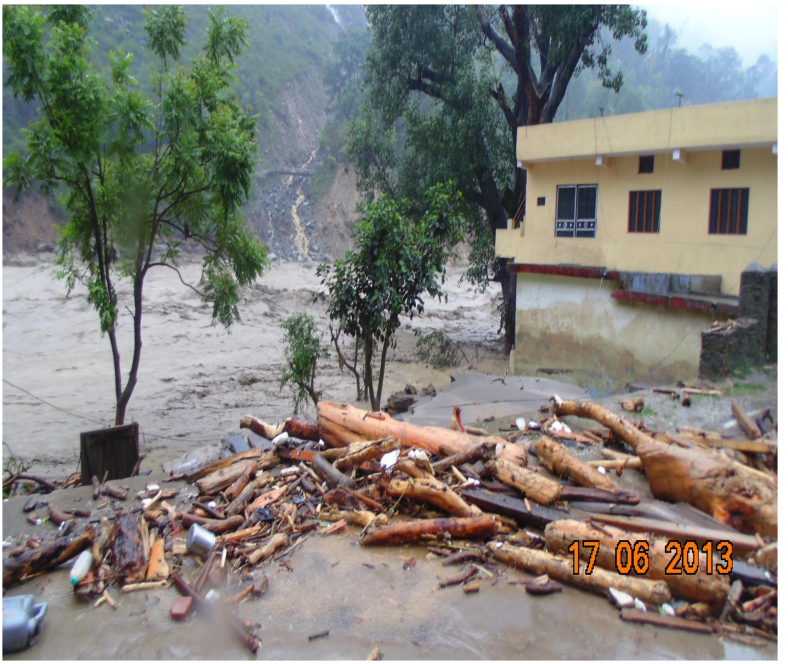

Fig. 4. Remnants of uprooted and washed away trees near Agastmuni after flood receded

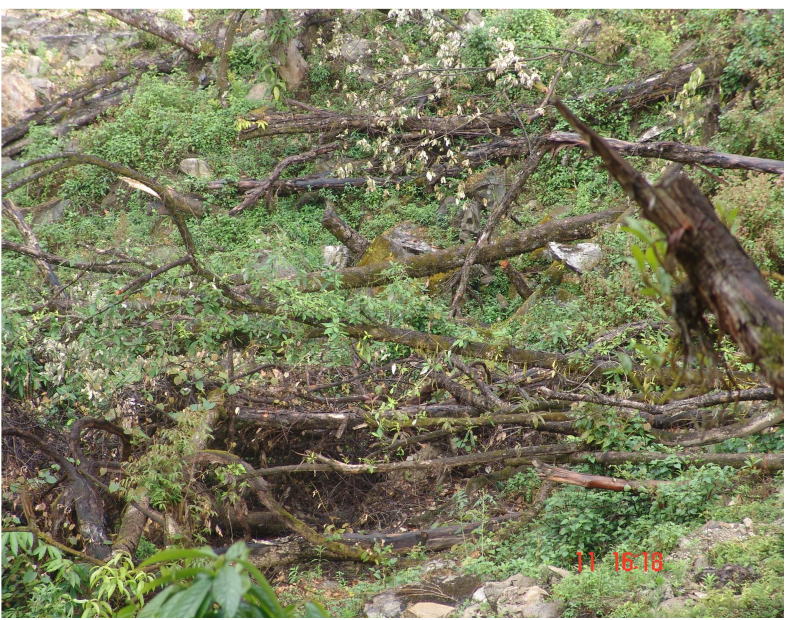

Fig. 6. Fallen trees in subtropical broad-leaved forest near river junction opposite Guptakashi

Environment Conservation Journal 


\section{Material and Methods \\ Study Area}

Majority of the landslides were observed within a crow-flight distance of $\sim 2 \mathrm{~km}$ from river bed (Fig. 1). The present study is limited to upper catchment of Mandakani river in Rudraprayag district of Uttarakhand state with an geographical area of $2,328 \mathrm{~km}^{2}$. It lies between $30^{\circ} 16^{\prime} \mathrm{N}-30^{\circ} 28^{\prime} \mathrm{N}$ latitude and $78^{\circ} 58^{\prime} \mathrm{N}-79^{\circ} 98^{\prime} \mathrm{N}$ longitude in Western Himalaya. Mandakani and Saraswati rivers originate from the Chorabari and Companion glacier regions and confluence near Kedarnath shrine. Other tributaries such as Son Ganga confluences with Mandakani river at Sonprayag and finally merges with Alaknanda river at Rudraprayag. The altitude varies from $800 \mathrm{~m}$ to $8000 \mathrm{~m}$ above mean sea level (http://rudraprayag.nic.in). The area receives rainfall both from south-west as well as from northeast monsoons. The mean annual rainfall is 1800 $\mathrm{mm}$. The study area represents tropical climate conditions at Rudrapryag to subzero temperature and permanent snow in glaciers. Forest cover of Rudraprayag district is about $57.57 \%$ of the total geographical (FSI, 2019). The tropical region has moist deciduous forest with Shorea robusta Gaertner f.; and Cassia fistula L., Senegalia catechu (L.f.) P. Hurter \& Mabb. etc. are the dominant species in dry deciduous forests and shrubs like Euphorbia royaleana, Lantana camara L. etc (fig. 7). Subtropical pine forests are dominated by Pinus roxburghii (Chir pine)(fig. 8). Himalayan moist temperate forests have trees like Aesculus indica (Colebr. ex Cambess.) Hook., Quercus spp., Prunus spp. etc., and shrubby species like Berberis asiatica Roxb. ex DC (Fig. 9). The Himalayan dry temperate forests are dominated by Cedrus deodara (Lamb.) G. Don, Picea smithiana (Wall.) Boiss. etc. whereas subalpine region is dominated by Rhododendron campanulatum, Taxus wallichiana Zucc., Betula utilis D. Don, Berberis spp. etc. (Fig. 10), moist alpine scrub dominated by Rhododendron spp. and dry alpine scrub dominated by Juniperus indica var. indica, Lonicera spp., etc. (Champion \& Seth, 1968) (Fig.11). The post disaster rehabilitation activities such as pitching of tents and shelters for officials, pilgrims and laborers, health centre, helipads, construction of new alternative foot-mule-track between Bhimbali-
Lincholi-Kedarnath and other facilitation centres have put huge biotic pressures on subalpine and alpine landscape leading to mass clearance alpine pastures with Ranunculus spp., Primula spp., Gentiana spp., Delphinium spp., Fragaria vesca, etc (fig. 12). Alpine scrub with Rhododendron spp. Berberis spp., Cotoneaster spp., etc. were also used for fire wood.

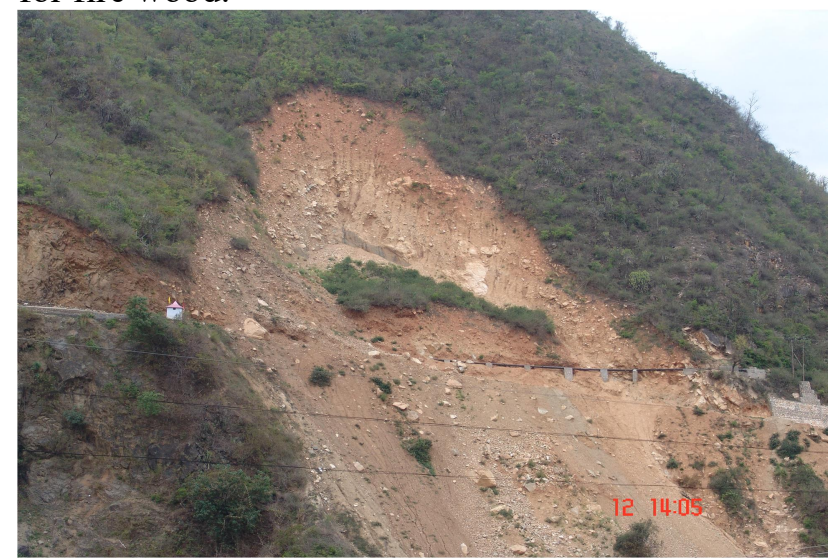

Fig. 7. Major landslide in tropical dense shrub north of Sumari Bhardar

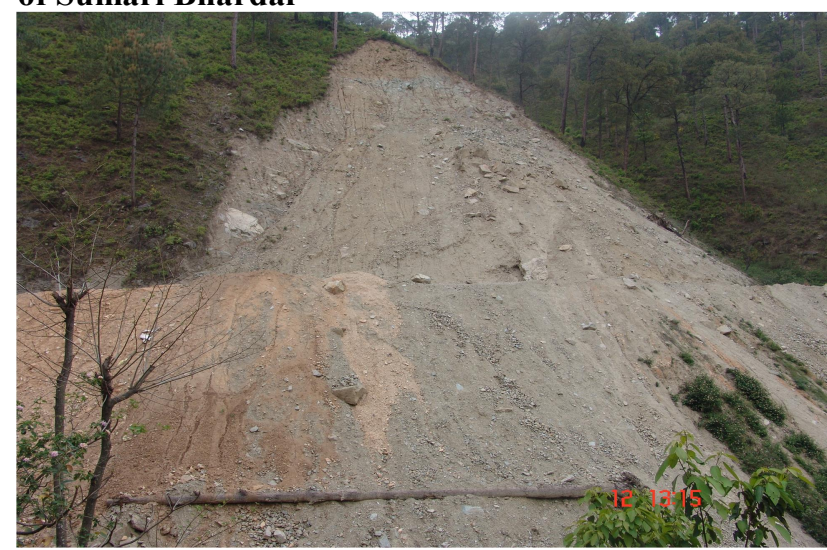

Fig. 8. Loss of Subtropical Pine forest opposite Agastmuni

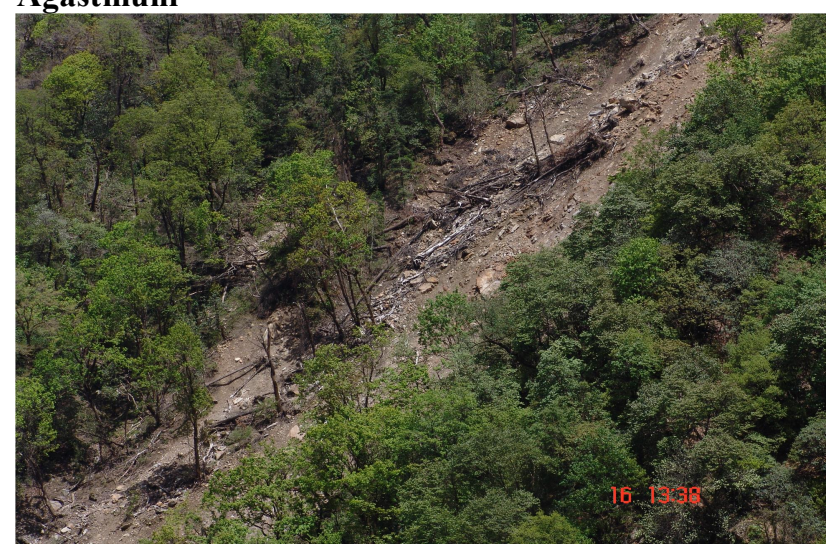

Fig. 9. Loss of subtemperate forest due landslide 


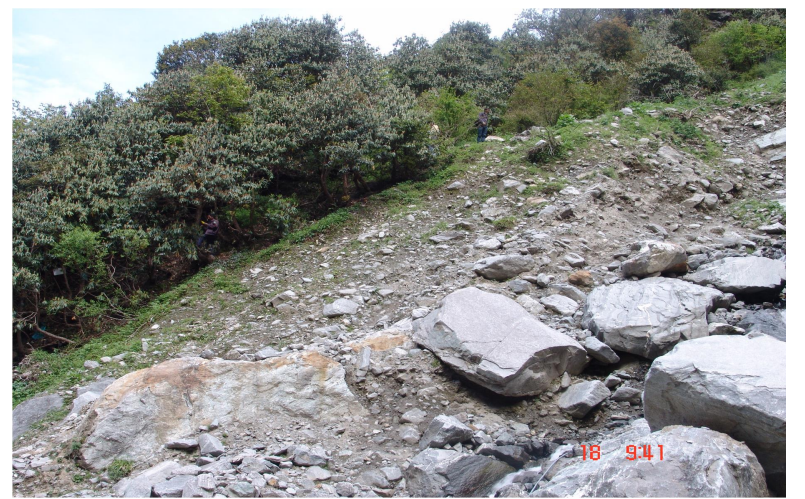

Fig. 10. Loss of Sub-alpine Rhododendron forest ahead of Bhimbali

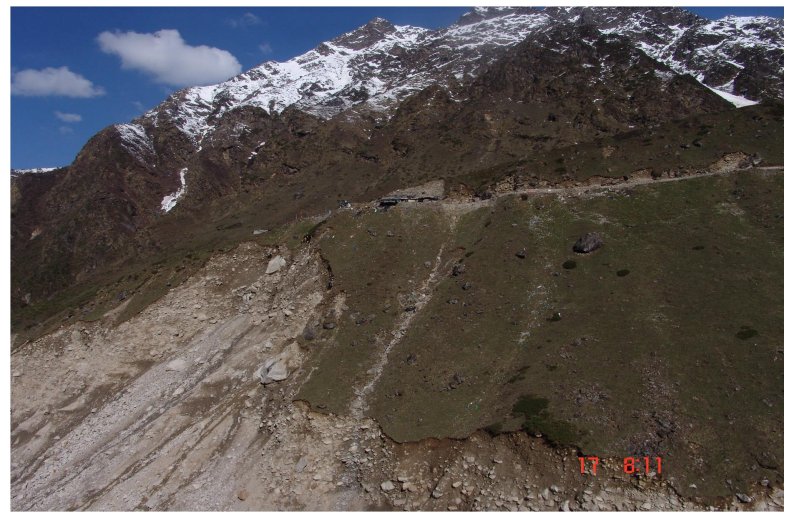

Fig. 11. Loss of alpine scrub and pastures enroute to Kedarnath

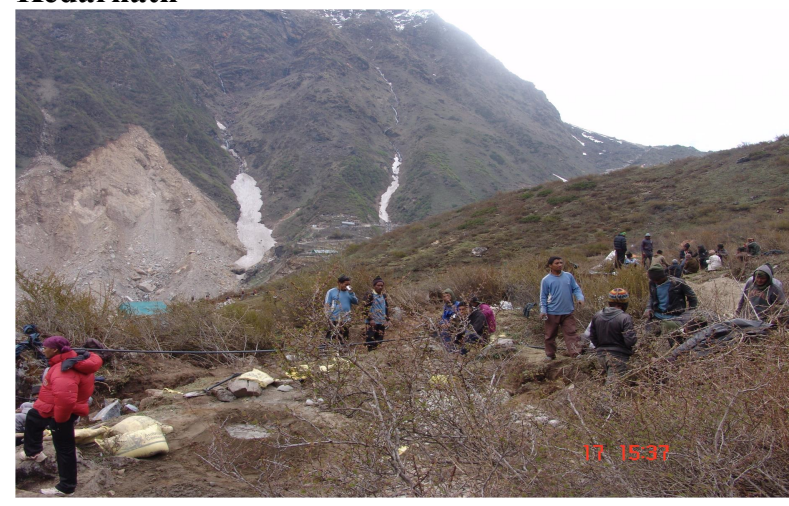

Fig. 12. Biotic pressure on Alpine scrub of BerberisRhododendron-Cotoneaster near Lincholi

\section{Data}

High resolution satellite data of IRS Linear Imaging Self-Scanning (LISS-IV) camera on RESOURCESAT-2 satellite of pre- and postdisaster were used. LISS IV has three spectral bands in Visible and Near infrared region (VNIR) with $5.8 \mathrm{~m}$ spatial resolution. Geo-corrected and Orth-corrected satellite images (Path-97/Row-49) were acquired for November 2012 (pre flood) and
December 2013 (post flood) from National Remote Sensing Centre Hyderabad. Both images were again co-registered using image to image rectification function. The Cartosat-1, DEM (H44H, H44I) was downloaded from http://bhuvan.nrsc.gov.in/data/download/index.php \#. A vector layer of river-bed was created from Rudraprayag to Kedarnath in GIS domain. Since, maximum landslides were reported along the roadside and river, roads are in close proximity of the rivers, therefore, a buffer of $2 \mathrm{~km}$ was created. The buffer layer was used as a mask area of our interests (fig. 13). Cartosat-DEM was used for climatic zonation of the forests to estimate forest type-wise biomass and carbon losses. The mean height for tropical forest was considered $900 \mathrm{~m}$, for subtropical forest $1800 \mathrm{~m}$, for temperate forest $2700 \mathrm{~m}$ and subalpine to alpine $2700 \mathrm{~m}$ to $3500 \mathrm{~m}$.

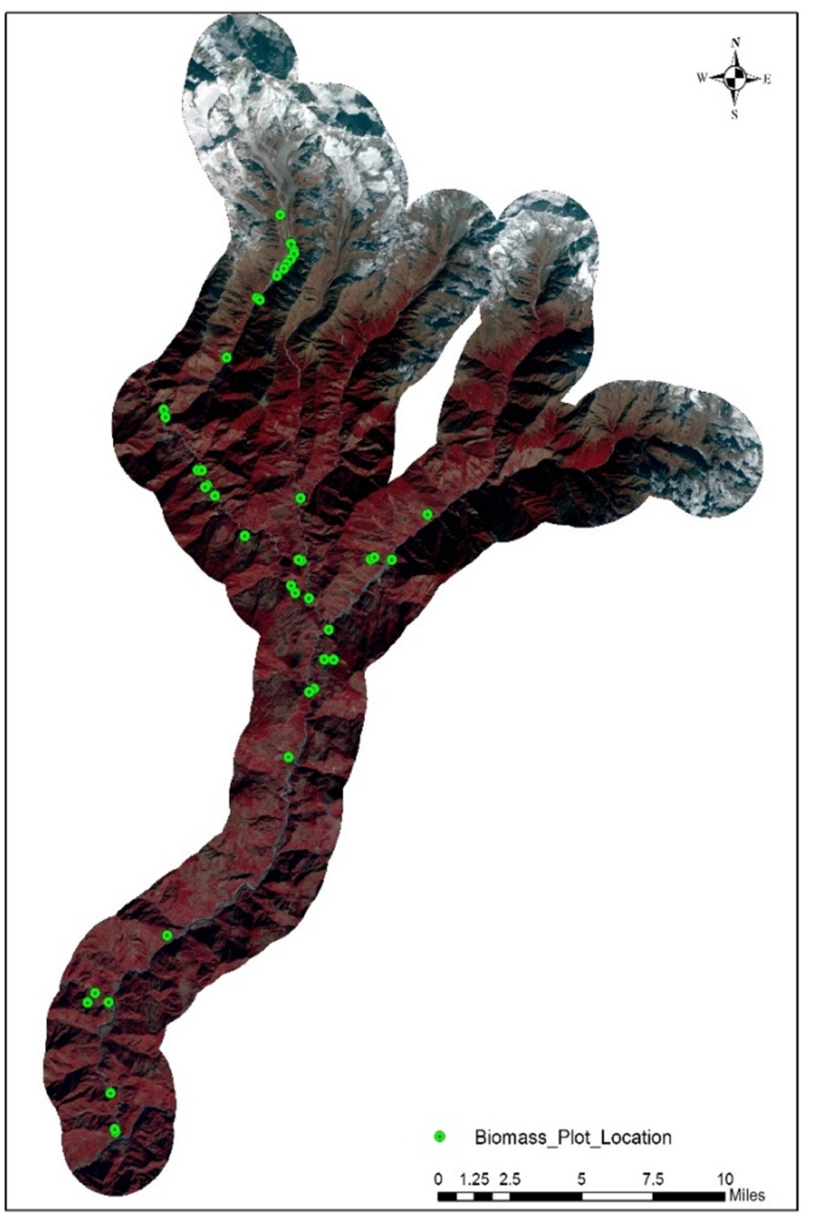

Fig. 13: False Colour Composite (4,3,2 RGB) of LISS IV data of post disaster event overlaid with sample locations 


\section{Kumar et al..}

\section{Satellite data processing}

The study area was covered in two scenes C and D of IRS-R2 LISS IV sensor. Although the data were geo-rectified and ortho-corrected but there were distortions in both the scenes. The dark pixel subtraction algorithm was applied to reduce the effect of haze. The images were radiometrically corrected by converting the reflectance to radiance using the formula:

$$
\begin{aligned}
\mathrm{L} \lambda & =\frac{\text { LMAX }- \text { LMIN }}{\text { QCALMAX }- \text { QCALMIN }} \\
& \times(\text { QCAL }- \text { QCALMIN })+\text { LMIN }
\end{aligned}
$$

where, $\mathrm{L}_{\lambda}=$ Spectral Radiance at the sensor (watts $\left./\left(\mathrm{m}^{2} * \mathrm{sr}^{*} \mu \mathrm{m}\right)\right)$

QCAL $=$ Quantized calibrated pixel value in DN

LMAX $=$ Spectral radiance scaled to QCALMAX

(watts $/\left(\mathrm{m}^{2} * \mathrm{~s} \mathrm{~s}^{*} \mu \mathrm{m}\right)$ )

LMIN = Spectral radiance scaled to QCALMIN

(watts $/\left(\mathrm{m}^{2} * \mathrm{~s} \mathrm{r}^{*} \mu \mathrm{m}\right)$ )

QCALMIN $=$ the minimum quantized calibrated pixel value in $\mathrm{DN}=1$

QCALMAX = the maximum quantized calibrated pixel value in $\mathrm{DN}=65535$.

The images were then geometrically co-registered (RMSE < 0.6) and mosaicked through average function to get the overall scene.

\section{Sampling Design and Field Data Collection}

NRSC (2013) inventoried old and fresh landslides due to disaster in Mandakani Valley using satellite data (www: bhuvan.noeda.nrsc.gov.in) and reported more than 275 major or minor landslides. A reconnaissance survey was carried out to design sampling strategy. A sampling strategy with $10 \%$ sampling intensity at 37 affected sites was arrived by considering size, climatic zones, forest type and density and accessibility. A total of 45 sample plots were laid covering different forest types from Rudraprayag to Kedarnath on both the sides of river in May 2014 in tropical, subtropical and temperate forests, scrubs and grasslands. The sample locations were identified on pre-disaster image considering similarity in spectral characteristics in adjacent or in the immediate surroundings of the affected areas using. Thirty plots of $20 \times 20 \mathrm{~m}$ were laid in forest, 8 plots of $10 \times 10 \mathrm{~m}$ in scrub, 60 samples of shrub in $5 \mathrm{~m} \times 5 \mathrm{~m}$ plots and 7 plots of $1 \times 1 \mathrm{~m}$ in grassland. The latitude, longitude, slope, aspect, elevation, etc. of each location were recorded by using GPS (Garmin $72 \mathrm{H})$ and Clinometer. Species-wise tree height with the help of Blume Leiss Hypsometer and girth at breast height (gbh) at $1.37 \mathrm{~m}$ using a metallic stable tape were measured. The specieswise number of bushes were counted in each subplots and were further categorized into small, medium and large bushes. The species-wise number of thick, medium and thin tillers were counted in each bush. The diameter, length and fresh weight of representative tillers were taken. These harvested samples were brought to lab for the assessment of dry weight. Grasses and litter were harvested. Fresh weight was taken in the field and $100 \mathrm{gm}$ of sample was oven dried for biomass and moisture content assessment.

Estimating tree Volume, Biomass and Carbon from field data

The gbh observations were converted into diameter units for calculating basal area and tree volume. The allometric equations developed by Forest Survey of India (1996) were used for assessment of tree volume. The volume equations for each species were carefully chosen considering the ' $n$ ' (total number of sample trees on which regression equation are based) and ' $\mathrm{R}$ ', (Coefficient of determination) for the same or nearest geographic region. The volume was multiplied with wood specific gravity (Forest Research Institute, 1996) to estimate the biomass (Biomass $=$ Volume $\times$ Specific Gravity). The biomass of oven dry weight of shrubs, herbs and litters were up-scaled to plotlevel before adding to the total biomass of all trees within the plot. The plot-level biomass was first upscaled to tonnes/ha and then down-scaled to pixel level (per pixel biomass). Plot-level biomass was converted to pixel-level biomass by simple transformation. Carbon assessment was done by multiplying the biomass values with conversion factor of 0.47 (IPCC, 2006). Regression model was developed between basal area and biomass of the trees to check for data errors.

\section{Spectral Modelling and Validation}

Different vegetation indices (VIs) were attempted for quantification and geospatial analyses of biomass through spectral modelling. The indices were: Simple Ratio (SR) (Birth, 1968), Normalized Differential Vegetation Index (NDVI) (Rouse et al., 1973), Modified Simple Ratio (MSR) (Chen, 1996), Green Normalized Difference Vegetation index (GNDVI) (Gitelson and Merzlyak 1996), Optimized Soil Adjusted Vegetation Index 54 Environment Conservation Journal 
(OSAVI) (Rondeaux et al., 1996) and Transformed Difference Vegetation Index (TDVI) (Bannari et al.., 2002) (Table 1). Each of the above mentioned index was tried using linear, power, exponential and logarithmic functions to establish find best correlation between observed biomass and vegetation index value for further geospatial modelling. Out of 45 sample plots, 30 were used to train the model and remaining 15 were used for the validation of the model. The index values were extracted using plot locations. The best equation was used for modelling both date datasets to obtain geospatial phytomass map of the area. The plots which were left for the validation of the model were overlaid on the derived phytomass map. The predicted biomass values were picked up with the help of location point vector in Arc GIS and plotted against the observed biomass for vlaidation.

Table 1. Vegetation indices and Formulas used in Modelling

\begin{tabular}{|c|c|c|c|}
\hline S.No. & Vegetation Indices & Formula & References \\
\hline 1 & Simple Ratio & $S R=\frac{\rho N I R}{\rho \operatorname{Red}}$ & Jordan, 1969 \\
\hline 2 & Modified Simple Ratio & $M S R=\frac{\left(\frac{N I R}{R e d}\right)-1}{\sqrt{\frac{N I R}{R e d}}+1}$ & Chen, J. 1996 \\
\hline 3 & $\begin{array}{ll}\text { Normalized } & \text { difference } \\
\text { vegetation index } & \\
\end{array}$ & $N D V I=\frac{\rho N I R-\rho \operatorname{Red}}{\rho N I R+\rho \operatorname{Red}}$ & Rouse et al.., 1974 \\
\hline 4 & $\begin{array}{l}\text { Green normalized difference } \\
\text { index }\end{array}$ & $N D V I=\frac{\rho N I R-\rho G r e e n}{\rho N I R+\rho G r e e n}$ & Gitelson et al.., 1996 \\
\hline 5 & $\begin{array}{l}\text { Optimized soil adjusted } \\
\text { vegetation index }\end{array}$ & $O S A V I=\frac{1.5 \times \rho N I R-\rho \operatorname{Red}}{\rho N I R+\rho \operatorname{Red}+0.16}$ & Rondeaux et al.., 1996 \\
\hline 6 & $\begin{array}{ll}\text { Transformed } & \text { difference } \\
\text { vegetation index } & \end{array}$ & $T D V I=\sqrt{0.5+\frac{\rho N I R-\rho R e d}{\rho N I R+\rho R e d}}$ & Bannari et al.., 2002 \\
\hline
\end{tabular}

\section{Results and Discussion}

Forest Cover Loss

The maximum net change in forest area was found in subtropical forest followed by tropical forest (Table 2). The least loss in the forests has been reported in both the Sub-Alpine and Alpine forests due to sparse and less vegetation cover. A moderate loss has been reported in Temperate forests. The details of the losses in different forest types may be seen at table 2 .

Table 2: Different Forest type-wise net Forest area loss in Mandakini valley.

\begin{tabular}{|l|l|l|l|}
\hline Forest Type & $\begin{array}{l}\text { Pre Flood Forest Area } \\
\text { (ha) }\end{array}$ & $\begin{array}{l}\text { Post Flood Forest Area } \\
\text { (ha) }\end{array}$ & $\begin{array}{l}\text { Net Change in Forest Area } \\
\text { (ha) }\end{array}$ \\
\hline Tropical & 135.730 & 18.670 & 117.060 \\
\hline Sub-Tropical & 187.640 & 0.080 & 187.560 \\
\hline Temperate & 24.970 & 2.395 & 22.575 \\
\hline Sub-Alpine & 6.620 & 0.050 & 6.570 \\
\hline Alpine & 7.005 & 0.0725 & 6.933 \\
\hline Total & 361.965 & 21.268 & 340.698 \\
\hline
\end{tabular}

Plot level biomass estimation

The plot-level biomass varied from $18.05 \mathrm{t} / \mathrm{ha}$ (Sub- variation in the plot level biomass may be attributed Alpine vegetation) to $252.95 \mathrm{t} / \mathrm{ha}$ (Sub-tropical to different growing conditions, vegetation types forest). A significant relationship $\left(\mathrm{R}^{2}=0.91\right)$ was and density, topographic variability and obtained through the linear regression model anthropogenic pressures across the landscape. between basal area of trees and biomass. The wide 
Spectral modelling above ground biomass

We performed 24 (6 indices and 4 models) derived coefficient $\left(\mathrm{R}^{2}\right)$ are given in Table 3. The regression models to find best coefficient of NDVI with its linear function was found to be most determination. The significant regression equations significant $\left(\mathrm{R}^{2}=0.893\right)$ represented by the equation: and $\mathrm{R}^{2}$ of NDVI, MSRVI, OSAVI and TDVI are $\mathrm{Y}=0.8818 \mathrm{x}+0.0054$, where, $\mathrm{Y}=$ Biomass $(\mathrm{t} / \mathrm{ha})$, given in figures $14,15,16$ and 17 , respectively and $\mathrm{x}=$ NDVI as independent variable.

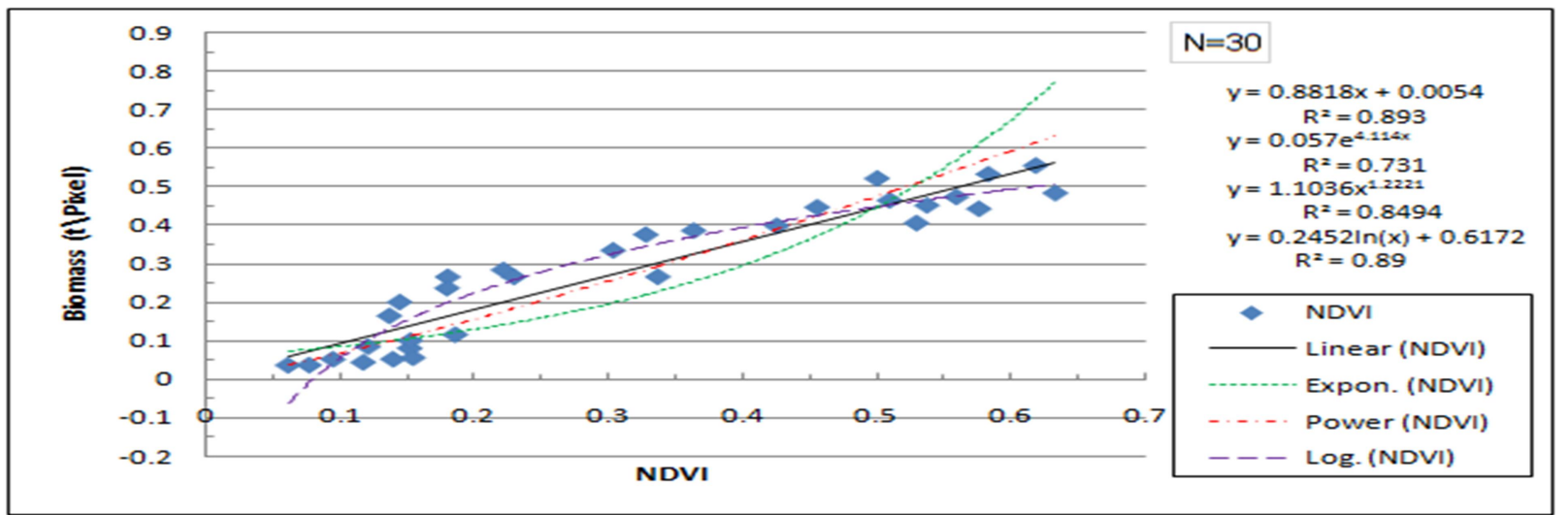

Fig. 14. Correlation between NDVI vs pixel-level biomass using multi-regression models.

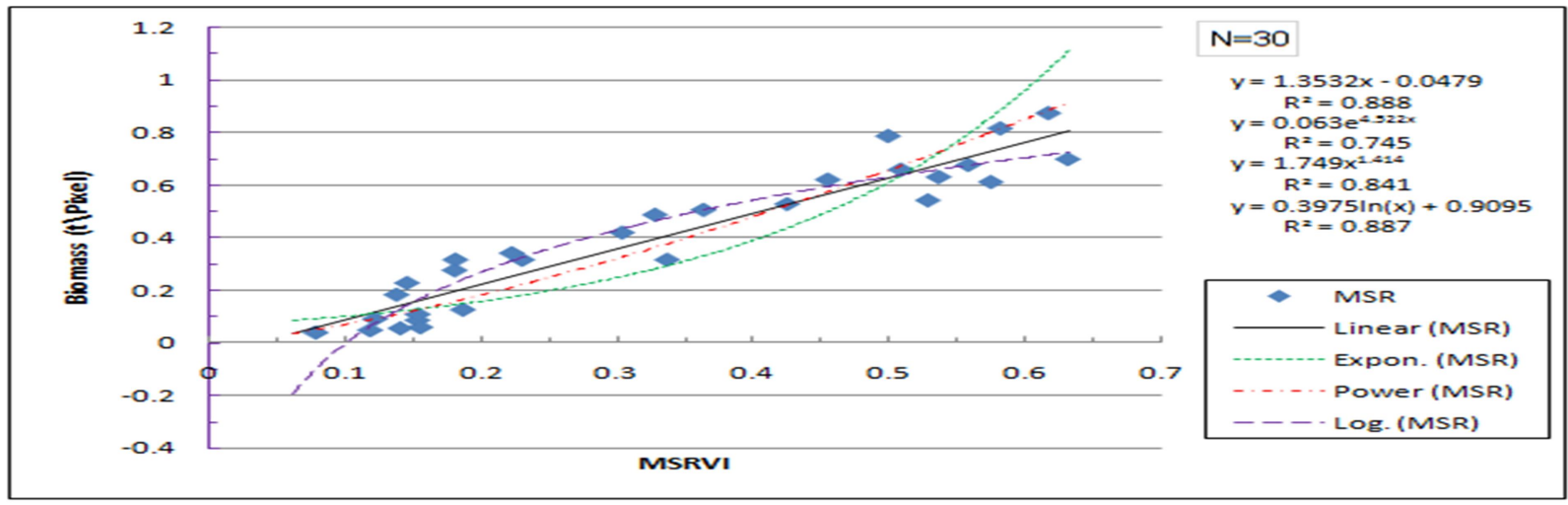

Fig. 15: Correlation between MSRVI and pixel-level biomass using multi-regression models

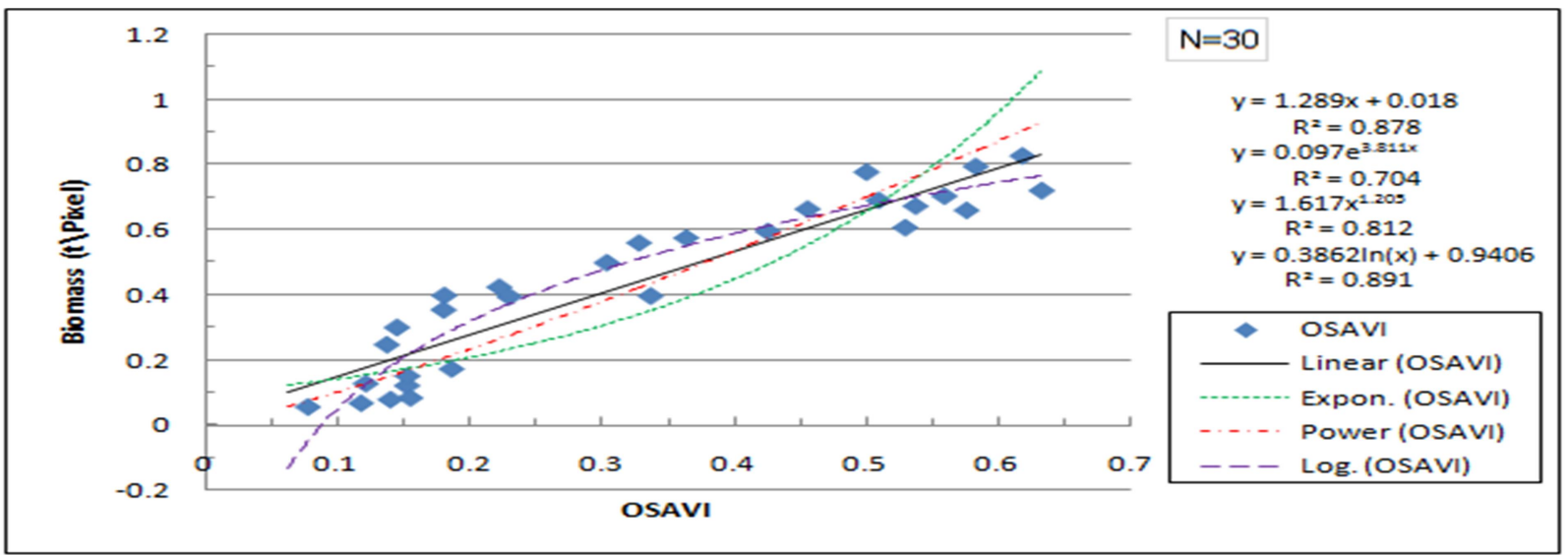

Fig. 16. Correlation between OSVI and pixel-level biomass using multi-regression models. 
Vegetation cover and carbon pool loss assessment

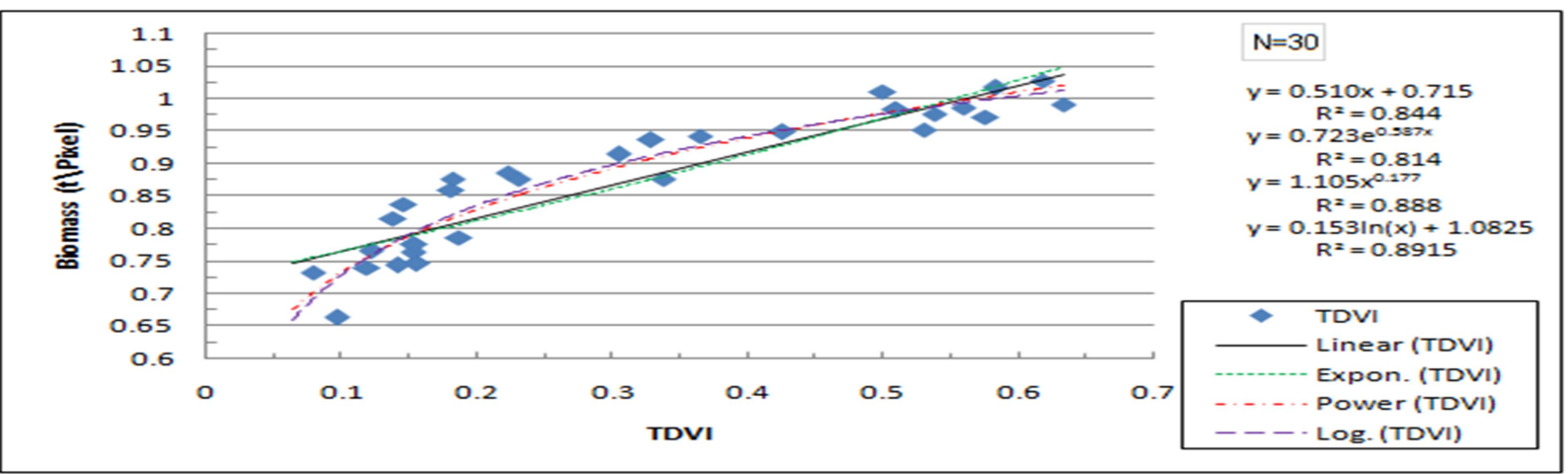

Fig. 17. Correlation between TDVI and pixel-level biomass using multi- regression models.

Table 3. Estimated $\mathbf{R}^{2}$ values and their $\mathrm{SE}$ for different regression models

\begin{tabular}{|c|c|c|c|c|c|}
\hline \multirow[t]{2}{*}{ Indices } & \multicolumn{5}{|c|}{ Regression Models ( $\mathbf{R}^{2}$ value) } \\
\hline & Linear & Exponential & Power & Logarithmic & $\pm \mathrm{SE}$ \\
\hline NDVI & 0.893 & 0.732 & 0.849 & 0.890 & 0.038 \\
\hline Simple Ratio & 0.780 & 0.416 & 0.442 & 0.775 & 0.101 \\
\hline MSR & 0.888 & 0.745 & 0.841 & 0.887 & 0.033 \\
\hline OSAVI & 0.879 & 0.704 & 0.812 & 0.891 & 0.043 \\
\hline GNDVI & 0.563 & 0.000 & 0.000 & 0.603 & 0.168 \\
\hline TDVI & 0.844 & 0.815 & 0.889 & 0.892 & 0.019 \\
\hline
\end{tabular}

The empirical model of biomass vis-à-vis NDVI whereas it was $0.67 \mathrm{t} /$ pixel in the post-flood. The with linear function was used to produce geospatial validation of the predicted vis-a-vis observed maps of biomass for both the pre-flood and post- biomass was done and a very significant coefficient flood period (Fig. 18 a,b). The maximum per pixel of determination $\mathrm{R}^{2}$ of 0.875 was obtained (Fig. biomass was $0.66 \mathrm{t} /$ pixel in pre-flood image 19).
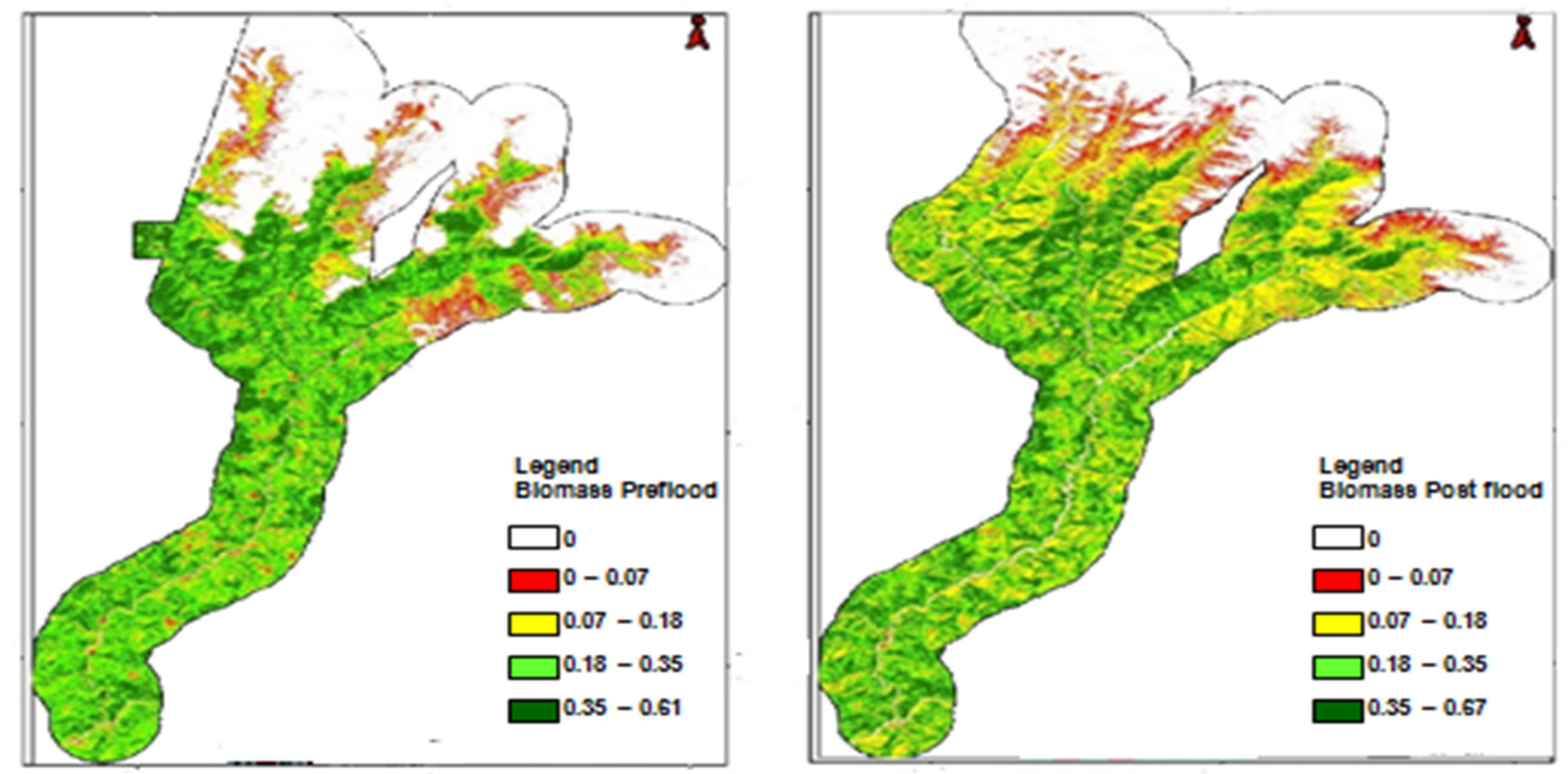

Fig. 18. Biomass (t/pixel) maps of Mandakini valley: (a) Pre-flood and (b) Post flood. 
Kumar et al..

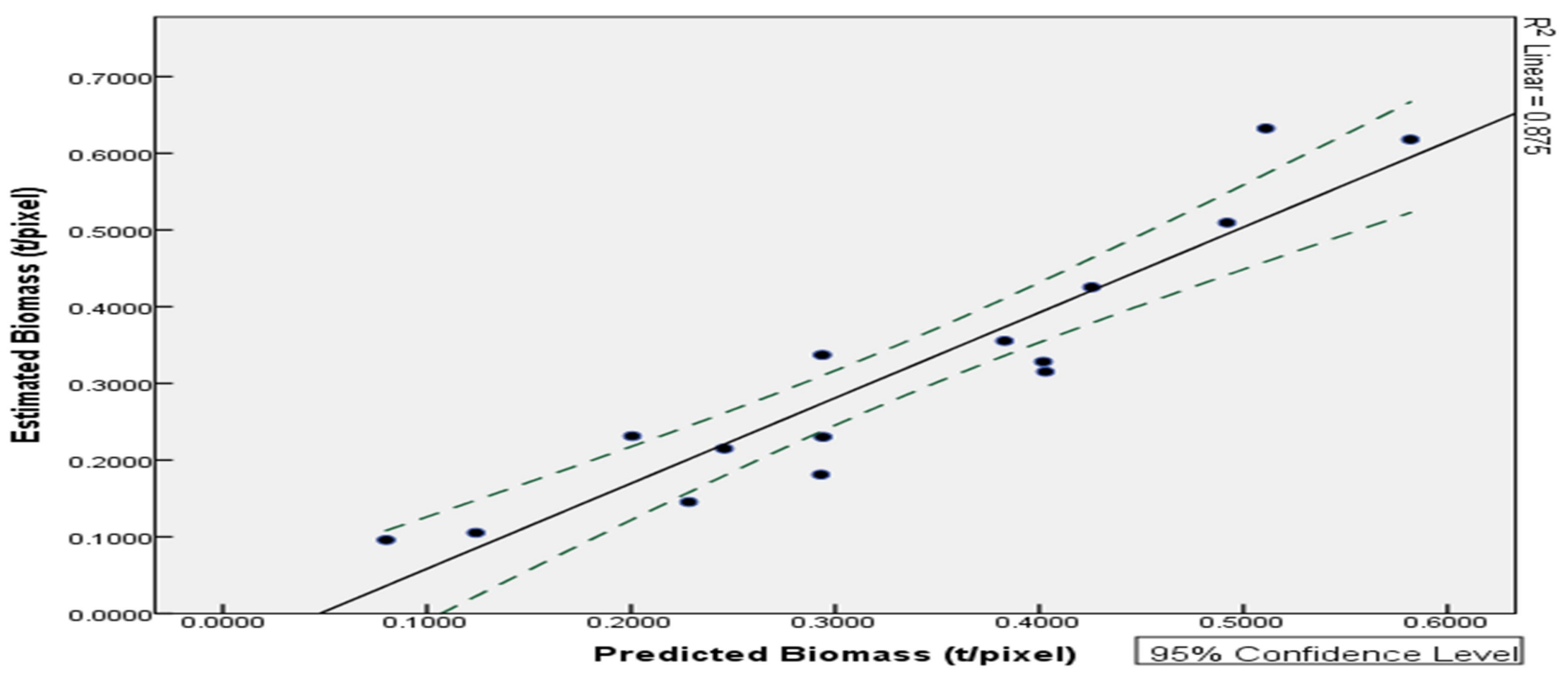

Fig. 19. Validation-Observed and Predicted Biomass values $(\mathrm{N}=15)$

Forest Phytomass and Carbon pool Assessment and Loss

The geospatial distribution of pre-flood and postflood biomass scenarios are given in Figs.7a,b. Forest type-wise total biomass before and after disaster is presented in Table 4. The maximum loss of Carbon has occurred in subtropical forest (13080.89 tonnes) followed by tropical forest (9027.13 tonnes). There is a Net loss of 52,055.80 tonnes of forest biomass between Rudraprayag and Kedarnath due to landslides that resulted in loss of $24,466.14$ tonnes of carbon. A total of $27,831.67$ tonnes biomass and 13080.88 tonnes of carbon have been lost from the sub-tropical forest between Phata and Sonprayag, which is maximum among all the forest types. The next major loss happened in tropical forest which lost about 19206.66 tonnes of biomass and 9027.13 tonnes of carbon. Losses in temperate forests were 3284.58 tonnes of biomass and 1543.75 tonnes of carbon. The biomass content of the sub-alpine and alpine forest is less as compared to other forest types. The net loss from sub-alpine forest and alpine forest type are 1160.63 tonnes and 572 tonnes, respectively.

The extreme rainfall conditions led to the outburst of Chorabari lake. Therefore, two factors, (a) high rain fall and (b) sudden release of water from lake together caused huge destruction. The sudden release of water led to rise in river water-level in narrow valleys, which caused cutting of valley bottom, river banks and soil erosion. The supersaturated soil on slopes could not hold weight of trees and soil and with gravity creeped uprooting thousands of trees. The most evident damage were in the Alpine and Sub-alpine regions. It may be either because of their proximity to the lake or the sparse vegetation dominated by herbaceous vegetation and open scrub on sandy soils - severely prone to erosion. In contrary to a general belief that the lack of vegetation on the mountain slopes accelerates the landslides, the present study finds that landslides have also occurred in slopes with good forest cover.We were able to map areas with $<0.01$ ha, using high resolution satellite data and detected the smallest landslide area inside the forest, which would otherwise be difficult on any medium to coarser resolution satellite data. However, narrow valleys with very steep slopes in Sonprayag to Kedarnath sector were under deep shadow and impacted the study. Among the various vegetation indices used for the mapping of vegetation biomass, the linear model derived from NDVI gave the most significant relation $\left(\mathrm{R}^{2}=0.893\right.$, $\mathrm{SE} \pm 0.038)$ followed by TDVI $\left(\mathrm{R}^{2}=0.892\right.$, SE $\pm 0.019)$ and OSAVI $\left(\mathrm{R}^{2}=0.891, \mathrm{SE} \pm 0.043\right)$.

The maximum per pixel biomass was $0.66 \mathrm{t} / \mathrm{pixel}$ in the pre-flood and $0.67 \mathrm{t} / \mathrm{pixel}$ in post-flood data in subtropical forests. A very little disagreement, which could be attributed to increase in biomass, in maximum limit of biomass between pre- and postflood maps indicates high accuracy and good fitness of the model. 
Vegetation cover and carbon pool loss assessment

Table 4: Different Forest type-wise net biomass and carbon loss in Mandakini valley (in tonnes)

\begin{tabular}{|l|l|l|l|l|l|l|}
\hline Forest Type & $\begin{array}{l}\text { Pre Flood } \\
\text { Biomass }\end{array}$ & $\begin{array}{l}\text { Post Flood } \\
\text { Biomass }\end{array}$ & $\begin{array}{l}\text { Net Change } \\
\text { in Biomass }\end{array}$ & $\begin{array}{l}\text { Pre Flood } \\
\text { Carbon }\end{array}$ & $\begin{array}{l}\text { Post Flood } \\
\text { Carbon }\end{array}$ & $\begin{array}{l}\text { Net Change } \\
\text { in Carbon }\end{array}$ \\
\hline Tropical & 24799.81 & 5593.15 & 19206.66 & 11655.91 & 2628.78 & 9027.13 \\
\hline Sub-Tropical & 31899.72 & 4068.05 & 27831.67 & 14992.87 & 1911.99 & 13080.89 \\
\hline Temperate & 4597.28 & 1312.70 & 3284.59 & 2160.72 & 616.97 & 1543.76 \\
\hline Sub-Alpine & 1203.68 & 43.05 & 1160.63 & 565.73 & 20.23 & 545.50 \\
\hline Alpine & 576.32 & 4.22 & 572.10 & 270.87 & 1.98 & 268.89 \\
\hline Total & 63076.81 & 11021.16 & 52055.65 & 29646.10 & 5179.95 & 24466.15 \\
\hline
\end{tabular}

The area-wise major destruction was observed in change scenarios, a few clips of FCC images and the upper stretches from Rambara to Kedarnath but modeled biomass in different ecoregions are biomass loss has been less (1732.73 tonnes), presented in figures $20 \mathrm{a}-\mathrm{b}$ and $21 \mathrm{a} \& \mathrm{~b}$. Figures 20 because upper reaches of sub-alpine and alpine (a) and (b) depict the major losses of forests in vegetation have thin grassy vegetation and poor Kharia and Kalimath region, that witnessed the biomass content. For the visualization and major loss of biomass/carbon due to flash floods. comparison of the pre- and post-landslides biomass
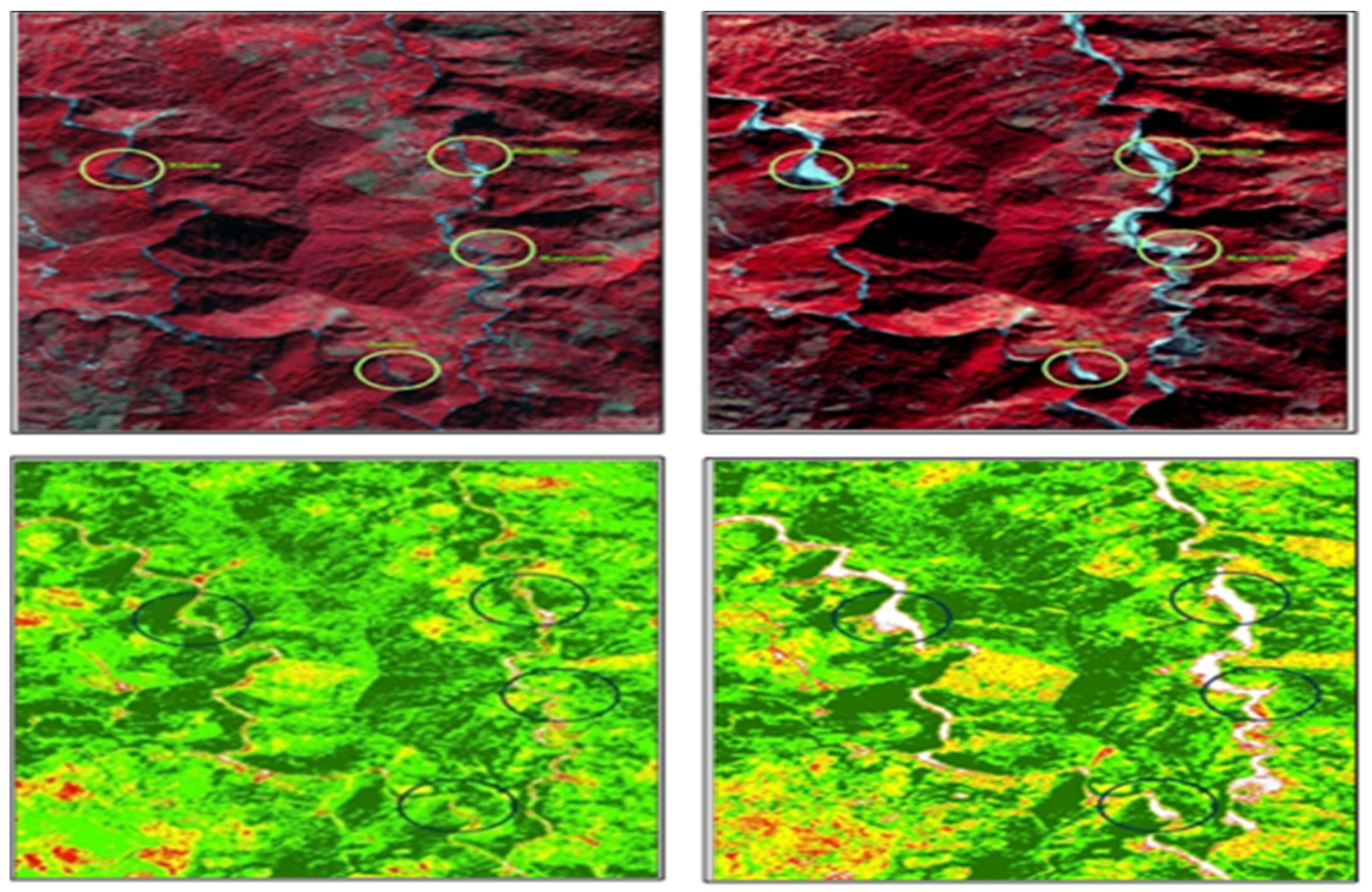

(a)

(b)

Fig. 20. LISS-IV images and biomass map (a) Pre-flood and (b) post-flood - conspicuous change area encircled in Mandakini valley 

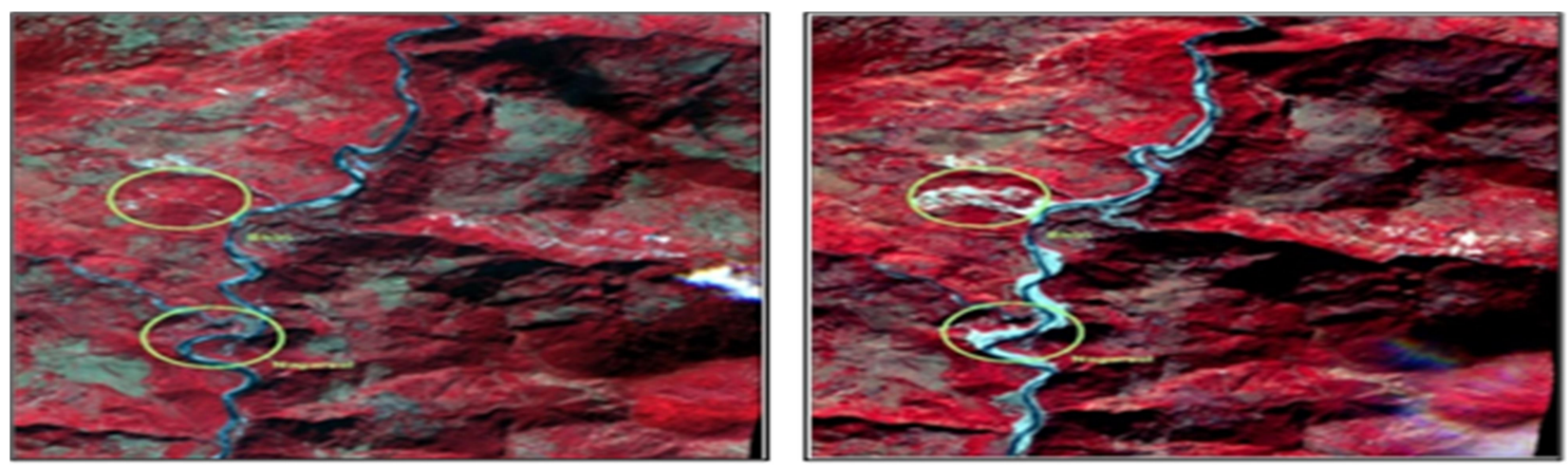

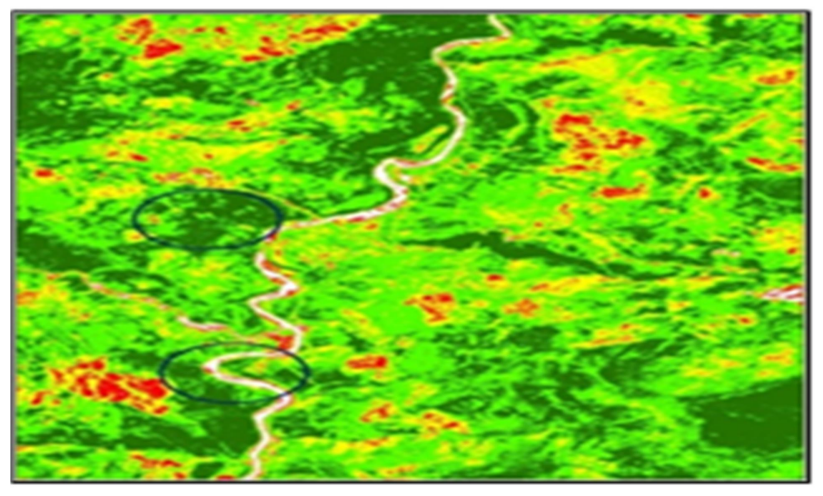

(a)

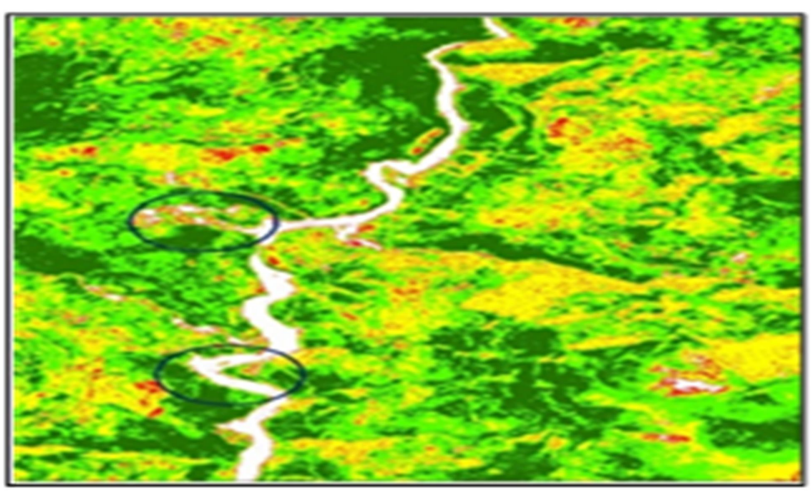

(b)

Fig. 21 . LISS-IV images and biomass map (a) Pre-flood and (b) post-flood - conspicuous change area encircled in Mandakini valley.

\section{Conclusion}

In order to provide better facilities to pilgrims and livelihood to local residents, the post-disaster activities under the concept of 'Built Better Back' have put tremendous biotic pressures in the valley between Bhimbali and Kedarnath. The construction of new approach foot-mule-track on the left bank of Mandakini river and other infrastructure development between Bhimbali-LincholiKedarnath has destroyed the local flora and disturbed the ecosystem of subalpine vegetation dominated Rhododendron and alpine vegetation by Berberis-Cotoneaster. It will be worth to study the degradation of vegetal cover, local biodiversity, ecosystem changes, etc. and possible invasion of exotic species

\section{Acknowledgements}

We wish to thank Dr. Y. V. N. Krishnamurthy, former director, IIRS for permission and all logistic support to carry out the field work and facilities to do analyses in labs. We extend our sincere thanks to the Head of departments, GSD and URSD, Dr. P.K Champati Ray and Dr. Pramod Kumar for sharing satellite data. We are grateful to all the officials of Uttarakhand Government located at Sonprayag, Bhim Gauda, Chinchauli and Kedarnath for arranging logistics, shelter and food. We also extend our thanks to cab driver Mr. Dadu. Last but not least, our gratitude towards Mr. Shahid, a PGD student, IIRS for his support during field work

\section{References}

Anbalagan, R. 1992. Landslide Hazard Evaluation and Zonation Mapping in Mountainous Terrain. Engineering Geology, 32: 269-277.

Bajpai, A., Wadhwa, N., \& Mahna, V. 2014. Environmental Impact Assessment: Uttarakhand Disaster (June-July 2013). International Journal of Life Sciences Research, $8-15$.

Bannari, A., Asalhi, H., \& Teillet, P. M. 2002. Transformed difference vegetation index (TDVI) for vegetation cover mapping. In IEEE Int. Geoscience and Remote Sensing Symposium, 5: 3053-3055. 
Bijalwan, A., Swamy, S. L., Sharma, C. M., Sharma, N. K., \& Tiwari, A. K. 2010. Land-use, biomass and carbon estimation in dry tropical forest of Chhattisgarh region in India using satellite remote sensing and GIS. Journal of Forestry Research, 21: 161-170.

Birth, G.S., \& McVey, G.R. 1968. Measuring the color of growing turf with a reflectance spectrophotometer. Agronomy Journal, 60(6): 640-643.

Champion, S.H., \& Seth, S.K. 1968. A revised survey of the forest types of India. A revised survey of the forest types of India.

Chen, J.M. 1996. Evaluation of vegetation indices and a modified simple ratio for boreal applications. Canadian Journal of Remote Sensing, 22(3): 229-242.

Chhabra, A., Palria, S. and Dadhwal, V.K. 2002. A spatial distribution of phytomass carbon in Indian forests. Global Change Biology ,8(12): 1230-1239.

Cutter, S.L., Emrich, C.T., Mitchell, J.T., Boruff, B.J., Gall, M., Schmidtlein, M.C. and Melton, G. 2006. The long road home: Race, class, and recovery from Hurricane Katrina. Environment: Science and Policy for Sustainable Development, 48(2): 8-20.

Dadhwal, V.K. and Shah, A. 1997. Recent changes in forest phytomass carbon pool in India estimated using growing stock and remote sensing based forest inventories. Journal of Tropical Forestry, 13: 182-188.

Das, P.K. 2013. 'The Himalayan Tsunami'-Cloudburst, Flash Flood \& Death Toll: A Geographical Postmortem. IOSR Journal of Environmental Science, Toxicology and Food Technology, 7(2): 33-45.

FSI. 2019. India State of forest report. Ministry of Environment and Forests, Government of India.

Gitelson, A.A. and Merzlyak, M.N. 1998. Remote sensing of chlorophyll concentration in higher plant leaves. Advances in Space Research, 22(5): 689-692.

Gupta, A.K., Shreeja, S.N. and Yunus, M. 2013. Uttarakhand Disaster 2013 - Floods and Landslides: Lessons of Ecology Not Yet Learnt. International Society of Environmental Botanists, 19(4).

Gupta, R., and Joshi, B. 1990. Landslide Hazard Zonation using the GIS Approach-A case Study from the Ramganga Catchment, Himalayas. Engineering Geology, 28: 119-131.

Gupta, S., Roy, A., Bhavsar, D., Kala, K., Singh, S. and Kumar, S.A. 2018. Forest Fire Burnt Area Assessment in the Biodiversity Rich Regions Using Geospatial Technology: Uttarakhand Forest Fire Event 2016. Journal of the Indian Society of Remote Sensing https://doi.org/10.1007/s12524-018-0757-3
Hallegatte, S. and Przyluski, V. 2010. The economics of natural disasters: concepts and methods. World Bank Policy Research Working Paper Series.

Indonesia, C.G.I. 2005. Preliminary damage and loss assessment, the December 26, 2004 natural disaster. Technical report, The Consultive Group on Indonesia.

IPCC 2006. IPCC guidelines for national greenhouse gas inventories. Prepared by the National Greenhouse Gas Inventories.

Jha, C.S., Rajashekar, G., Kiran, C.T., Singhal, J., Reedy, C.S., Singh, J., et al.. 2016. Monitoring of forest fires from Space- ISRO's initiative for near real time monitoring of recent forest fires in Uttarakhand. Current Science, 110: 2057-2060.

Kahlon, S., Chandel, V.B. and Brar, K.K. 2014. Landslides in Himalayan Mountains: A Study of Himachal Pradesh, India. International Journal of IT, Engineering and Applied Sciences Research, 3(9): 28-34.

Kala, C. P. 2014. Deluge, disaster and development in Uttarakhand Himalayan region of India: challenges and lessons for disaster management. International Journal of Disaster Risk Reduction, 8: 143-152.

Kale, M.P., Ravan, S.A., Roy, P.S. and Singh S.S. 2009. Patterns of carbon sequestration in forests of Western Ghats and study of applicability of remote sensing in generating carbon credits through afforestation/reforestation. Journal of Indian Society Remote Sensing, 37: 457-471.

Kanungo, D.P., Arora, M.K., Sarkar, S. and Gupta, R.P. 2006. A comparative study of conventional, ANN black box, fuzzy and combined neural and fuzzy weighting procedures for landslide susceptibility zonation in Darjeeling Himalayas. Engineering Geology, 85(3): 347-366.

Kessarkar, P.M., Srinivas, K. Suprit, K. and Chaubey, A.K. 2011. Proposed landslide mapping method for Canacona region. National Institute of Oceanography, (Council of Scientific \& Industrial Research, Dona Paula, Goa)pp. 5.

Kumar, A. 2013. Demystifying a Himalayan tragedy: study of 2013 Uttarakhand disaster. Ecology, 1(3): 106-116.

Kumar, R., Gupta, S.R., Singh, S., Patil, P. and Dhadhwal, V.K. 2011. Spatial distribution of forest biomass using remote sensing and regression models in Northern Haryana, India. International Journal of Ecology and Environmental Sciences, 37(1): 37-47.

Lang, D., Molina-Palacios, S., Lindholm, C. and Balan, S. 2012. Deterministic earthquake damage and loss assessment for the city of Bucharest, Romania. Journal of Seismology, 16(1): 67-88 
Manish, S., Mishra Sunil, K. and Shuchi, T. 2013. The Impact of Torrential Rainfall in Kedarnath, Uttarakhand, India during June, 2013. International Research Journal of Environment Sciences, 2(9): 34-37.

Mehrotra, G., Sarkar, S., Kanungo, D. and Mahadevaiah, K. 1996. Terrain analysis and spatial assessment of landslide hazards in parts of Sikkim Himalaya. Geological Society of India, 47: 491-498.

Mishra, S.R. 2015. Earthquake aftermath: Support Nepal to rebuild sustainably. Nature, 524(7563): 35-45.

Nagarajan, R., Mukherjee, A., Roy, A. and Khire, M. 1998. Temporal remote sensing data and GIS application in landslide hazard zonation of part of Western Ghat, India. International Journal of Remote Sensing, 19: 573-585.

Naithani, A.K., Kumar, D. and Prasad, C. 2001. Could Phata Byung, Uttaranchal landslide be prevented? Current Science, 82: 921-923.

Pachauri, A. and Pant, M. 1992. Landslide hazards mapping based on geological attributes. Engineering Geology, 32: 81-100.

Pandey, U., Kushwaha, S.P.S., Kachhwaha, T. S., Kunwar, P., and Dadhwal, V.K. 2010. Potential of Envisat ASAR data for woody biomass assessment. Tropical Ecology, 51: 117124.

Pareta, K. and Pareta, U. 2012. Landslide modeling and susceptibility mapping of Giri river watershed, Himachal Pradesh (India). International Journal of Science and Technology, 1(2): 91-104.

Patil, P., Singh, S. and Dadhwal, V.K. 2012. Above ground forest phytomass assessment in southern Gujarat. Journal of Indian Society of Remote Sensing, 40(1): 37-46.

Ramachandran, A., Jayakumar, S., Haroon, R.M., Bhaskaran, A. and Arockiasamy, D.I. 2007. Carbon sequestration: estimation of carbon stock in natural forests using geospatial technology in the Eastern Ghats of Tamil Nadu, India. Current Science, 92: 323-331.

Rao, K.D., Rao, V.V., Dadhwal, V.K. and Diwakar, P.G. 2014. Kedarnath flash floods: a hydrological and hydraulic simulation study. Current Science, 106(4): 598.

Rondeaux, G., Steven, M. and Baret, F. 1996. Optimization of soil-adjusted vegetation indices. Remote sensing of environment, 55(2): 95-107.

Rouse, J.,R. Haas, J. Schell, and D. Deering. 1973. Monitoring Vegetation Systems in the Great Plains with ERTS. Third ERTS Symposium, NASA: 309-317.

Sarkar, S., Kanungo, D. and Mehrotra, G. 1995. Landslide hazard zonation: a case study in Garhwal Himalaya, India. Mountain Research and Development, 15(4): 301-309.

Scawthorn, C., Flores, P., Blais, N., Seligson, H., Tate, E., Chang, S. and Lawrence, M. 2006. HAZUS-MH flood loss estimation methodology. II. Damage and loss assessment. Natural Hazards Review.

Sengupta, A., Gupta, S. and Anbarasu, K. 2010. Landslidesinvestigations and mitigation in eastern Himalayan region. International Journal of the Indian Roads Congress, 71(2): 133-142.

Soni, P., Vasistha, H.B. and Rawat, A. 2008. Natural Resources Depletion and their Ecological and Economical Valuation in Varunavat landslide of Uttarkashi District, Garhwal Himalayas. Landslide Management Present Scenario \& Future Directions, (Vol.1).

Thakur, T. and Swamy, S.L. 2010. Analysis of land use, diversity, biomass, $\mathrm{C}$ and nutrient storage of a dry tropical forest ecosystem of India using satellite remote sensing and GIS techniques. International Forestry and Environment Symposium, 15: 273-278.

Wyss, M. 2005. Human losses expected in Himalayan earthquakes. Natural Hazards, 34(3): 305-314. 